Global Conferences Series:

Social Sciences, Education and Humanities (GCSSSEH), Volume 2, 2019

The $2^{\text {nd }}$ International Conference on Sustainable Development \& Multi-Ethnic Society

DOI: https://doi.org/10.32698/GCS.01103

\title{
Flipped Classroom Teaching Methods Influencing Learning Methods among School Students
}

\author{
Siti Nurazmira Yusoff ${ }^{1}$, Mohd Mahzan Awang ${ }^{2}$, Abdul Razaq Ahmad ${ }^{3}$ \& Anuar \\ Ahmad $^{4}$ \\ ${ }^{1234}$ Faculty of Education UKM, MALAYSIA \\ E-mail: sitinurazmirayusoff@gmail.com
}

\begin{abstract}
Education in Malaysia is now in the phase of applying $21^{\text {st }}$ century learning that desperately needs thinkers who are capable of thinking creatively, innovatively and can generate new ideas and ideas to enable them to complete globally. To that end, education today provides students with the opportunity to go through the process of learning based on their own experiences so that it can be applied to daily learning, especially in the classroom. One of the effective teaching methods is to use the Flipped Classroom learning method, which is a method of transferring lectures, which requires students to first understand concepts in a particular topic through self-study before teachers can teach them and facilitate them. The flipped classroom learning methods also requires a flip-flop in conventional classroom learning strategies and methods in which teachers first provide the task of asking their students to complete the task before engaging in the learning activities. This flipped classroom learning has the ability and potential to influence how students learn in the effective implementation of the learning process. This learning process gives students the opportunity to focus, demonstrate the ability to create and at the same time work on better ideas. Therefore a flipped classroom learning process can attrack and excite students' interest in learning using their own experiences or knowledge. In addition, the learning process in the classroom can be fully utilized to carry out collaborative activities and strengthening students individually. As a result, this method will have a positive impact on students in receiving knowledge more easily, enjoyably and effectively. Therefore, teachers need to be smart in developing their learning strategies to produce students who are creative, innovative and able to generate new ideas.
\end{abstract}

Keywords: History Education, Effective Learning, Issues and Challenges of History Education, PAK-21

\section{Introduction}

Copyright $\odot$ 2019, the Authors. Published by Redwhite Press.

This is an open access article under the CC BY-NC license

(http://creativecommons.org/licenses/by-nc/4.0).
The National Philosophy of Education should be used as a guide towards establishing reforms in the field of education that have the potential to humiliate mankind destroying or 
damaging existing plans (Khailani A.Jalil, 2011). Various efforts have been made by the Ministry Of Education Malaysia to create and generate ambitions in the Malaysian Philosophy of Education which seeks to build potential individuals from various facets of physical, spiritual, emotional and spiritual goals to enable individuals to compete with developed countries.

Teaching is a process of disseminating knowledge and skills so that students can learn and master its content effectively. In Malaysia, a $21^{\text {st }}$ Century Learning Method (PAK-21) was introduced. This method trains students to think, collaborate and creatively to create learning ideas. The string of learning from PAK21 also enables change agents, namely teachers to diversify their methods during the learning and facilitating process $(\mathrm{PdPc})$. According to Mohd Zain et.al (2012) stated that teaching methods that meet the quality of student learning can meet the goals and direction of the country. One of the uses of Flipped Classroom teaching method is that students learn independently to convey information about the lessons. This method is one of the $21^{\text {st }}$ Century teaching pedagogy or techniques because the Flipped Classroom is different from the traditional teaching methods.

The Flipped Classroom method is a studentcentered learning method that requires students to actively engage in creative and critical thinking. According to Baker (2000), flipped classroom in inverted classroom was a student-centered method of learning and was first introduced in 2000. This method gained attention after the popularity of two school teacher, Bergmann and Sams in 2009, through the use of video and learning activities online. This method differs from the conventional way of learning that is almost entirely dependent on the teacher's preparation of the material while the students only accepts the knowledge and than learn the learning activity after understanding the topic. This method of learning sometimes contributes to the passive learner compared to the flipped classroom approach which actively alters the learning environment as all students are prepared with their own information before implementing the PdPc process.

\section{Problem Statement}

The field of education that is expected to produce quality products must start with the development of highly skilled people and their personalities. However, sometimes students in the school are not given the opportunity to learn on their own. It is even more focused on traditional methods that take place once in a while. As expected, students should be given the opportunity to think independently in order to create something more creative, critical and innovative in order to further their potential. So, why not combine a method that is more effective than using the old method that sometimes students have a limitations to think outside the box. Fun learning comes from self-interest and sometimes from the fnfluence of the environment involved in the conduct of learning activities.

Other than that, there are some students who only expect a one way learning by relying solely on the teacher's preparation of materials. As a result, they are lazy in thinking, less expressive and developing ideas and passivity in the classroom. Therefore, students will not be active, creative and critical as well as lack of confidence when confronted with the environment causing them to be less intelligent in solving problems. Here, students should be trained from an early age to contribute ideas, be creative and critical, active and innovative.

\section{Literature Review}

The flipped classroom learning approach has been applied in school and higher learning instituations has been a positive reaction among the students themselves and this method also enhances the students' understanding. Pang and Yap (2014) in their study stated that the flipped classroom learning method received positive feedback from the students and that the learning outcomes were achieved as expected. Meanwhile, studies by Flumerfelt and Green (2013) found that there was a percentage increase in Mathematics, Science, English and Social Sciences after implementing the flipped classroom method. This proves that this method helps to improve student' understanding even for difficult subjects.

Generally, the flipped classroom method has no specific limitations as it can be done in a variety of ways depending on the creative attitude and wisdom of the teacher himself. According to Jiugen (2014) the method of flipped classroom does not depend solely on online learning but can use any kind of material as long as it benefits the students. In a study by Lockwood (2013) he combined the flipped classroom method with another pedagogy that is inquirybased learning. He conducts investigative learning so that his students have more opportunities to engage in group and hands on activities.

Therefore, it is clear that this flipped classroom learning method is best used for both student and their learning as it is beneficial. It can even be diversified appropriately to achieve the purpose of learning.

\section{The Flipped Classroom Concept}

The transformation in national education today promotes the $21^{\text {st }}$ Century Learning method. It encourage student-centered learning and familiarize students with self-directed learning 
to better understand the topics they are through out the learning process. According to Bawaneh et. al (2011) this can be achieved through effective teaching strategies and student-centered learning. The method of flipped classroom is also known as interver classroom is a reverse method. Flipped classroom is a pedagogical method or teaching strategy that differs from traditional teaching strategies. Through this method there are many ways teachers can provide for the success of the learning process for students. It begins with the preparation of assigments such as videos, practice questions sheets, coursework, quizzes and presentations of students work. In this situatition the teacher acts only as a facilitator to launch activities and to activate the classroom to ensure that students are ready to develop ideas that are more focused on Higher Order Thinking Skills (HOTS). Indirect learning is a student-centered learning process where students are encouraged to actively participate in the classroom. Through self-directed learning, students are able to take more responsibility for their learing (Mgill, 2010).

In addition, this strategy encourages constructivisme between teachers and students and pupils with students. Vgotsky (1978) defines Social Constructivism Theory as a social learning context. According to Vgotsky, communities play an important role in the formation of optimum learning through the More Knowledge Other (MKO) and the Zone of Proximal Development (ZPD). More Knowledge Other is that students actively learn through knowledge building, idea processing, assignment, discussions, patterns that can be learned and understood and solve problems independently. Zone of Proximal Development is the potential and ability of students to learn optimally and apply More Knowledge Other (MKO). Therefore, teaching and learning that use the Flipped Classroom method can encourage constructivism between students and teachers and it also stimulates the way or style of learning. If students were previously passive, lack of confidence in their opinions may turn into active and confident learning

\section{Flipped Classroom Learning Application}

The Flipped Classroom has two phases, which are the learning phase outside the classroom and the learning phase in the classroom according to the needs of the curriculum and students level. The Outdoor Learning Phase (PKL) require teachers to provides exercises or assignments for students to obtain the material through self-discovery. The In-Class Learning Phase (PLK) teachers are engaged in learning activities once the students are ready to present the ideas and information they have acquired. To succeed this method teachers can also do this in two ways, individually and in groups and to ensure that students are ready to continue learning.

In the implementation of the flipped classroom method, teachers can provide the material of a topic in the form of videos, slides, work sheets and others. Teachers will then ask students to watch videos, create assignments, find materials, prepare scrapbooks, answer quiz question and many more. During this phase it is advisable for the teacher to set a time period for the students to obtain materials or to complete assignments to facilitate the learning process that will be carried out later. That, the process of teaching and learning in the classroom is implemented using the materials obtained by the students. During the implementation the teacher acts as facilitators and can determine appropriate activities for use during $\mathrm{PdPc}$ sessions such as forums, debates, quizzes, discussions and others. At this stage teachers should also play the role of facilitators to encourage student angagement, control the atmosphere and conduct of learning activities so that they are active, harmonious and exciting.

\section{Self-Learning in Flipped Classroom Methods}

Flipped Classroom learning strategies are one of a kind learning that utilizes a learning approach that gives students space and opportunity to learn on their own. This is because only the students themselves are able to do the best because they have different abilities, interests, needs, attitudes and levels. According to Metcalfe (2009); Finley et. al (2009); Tullis and Benjamin (2012) state the ability to guide learning activities such as what to learn, how long to learn and when to need learning. Based on this study, through the flipped classroom method, students will self-regulate on how to gather materials and generate ideas. However, teachers should act as facilitators or methors in their PdPc process so that the learning environment is flexible, comfortable and stress-free.

Therefore, the advantage of self-directed learning is that students can apply their learning skills to learn,sharpen and increase their knowledge independently, learn for their own needs and take responsibility for their own learning this flipped classroom method gives students the opportunity to gain these benefits while doing their assignments.

\section{Flipped Classroom Changes How Students Learn}

Conventional methods are usually initiated by teachers in the preparation of teaching materials. Compared to the flipped classroom method which uses' reverse 'methods whereby it requires students' first effort to find the material and share with their friends during their PdPc activities. Through this method is can be seen that students are engaged in their 
behavior and thinking to come up with ideas and complete assigned tasks. As stated by Parson and Taylor (2011) student engagement can be seen in many aspects, both behavioral, affective and cognitive.

In addition, Stone (2012) believes that the advantage of the flipped classroom method is that it provides more quality space and time between teachers and students. Student-teacher interaction is the key to an active and meaningful learning. Process meaning here the space and time allocated to a student is a very important and meaningful when it is best used. In the PdPc process teachers and students are able to use the time optimally and qualityly as students are prepared with the necessary materials or information.

\section{Findings and Discussion}

The Flipped Classroom method is a flexible learning method and it is not limited to one method but it can be used in various educational disciplines and levels. This learning can also be done on all levels of students, both normal and special students. This finding can be illustrated by a study conducted by Siegle (2013) showing that the flipped classroom method works well for special students and for gifted students. On the other hand, for students with high intelligence, the flipped classroom method acts as an enrichment process (Siegle, $2013 \mathrm{~b}$ ).

In addition, according to a study conducted by Toto and Nguyen (2009), Lage, Platt and Treglia (2000) shown that, students are more interested in 'Hands-on' activities and feel more comfortable than listening in the classroom. So, the flipped classroom method is seen to enhance student achievement, improve communication and teamwork (Herreid and Schiller, 2013). This is because through the flipped classroom method students are given the opportunity to obtain information before the class starts. Indirectly, the pupils are engaged in learning about the content or topic through their inquiries.

Previous studies have also found that students who are unprepared for the learning provided, will come to the next class in a 'blank' state of mind, not engage in the activities provided and easily bored while learning (Mukherjee, 2013). Noraini Mohamed Noh et.al (2017) also stated that students feel bored and lost interest in their learning process when the teachers used the one way strategy, less engaging with students and relying more on textbooks. This is very different from the flipped classroom method which can influence the learning style of the pupils in a more and self-reliant that makes the student enjoy learning. In addition to engage effective learning activities, teachers are also able to make full use of quality time available. This is reflected in time spent in the classroom. Teachers spending full time for collaborative and reinforcing learning for students individually, thus prolonging the discussion time (Wei Zheng et.al, 2014). Therefore, the time allocated to learn topic is very important for students to fully understand the topic they studied.

Therefore, through previous studies, this flipped classroom learning method has a positive impact on the learning activities. Other than, providing students with a better chance of mastering the learning content, students will also enjoy the fun and satisfaction of learning.

\section{Summary}

Fun learning will be built upon the participation of all the teachers and pupils to stimulate the learning sessions. However, it can be a lot of fun to come up with a variety of strategies or methods that can help attract students as they continue their learning sessions. Choosing a smart strategy by a teacher will produce more critical, creative and innovative individuals as well as produce effective learning. It will also have a positive impact on the way or style of learning. The flipped classroom method can be followed and various improvements can be at the discretion of the teacher during the teaching process so that pupils can master the learning effectively.

\section{References}

[1] Bawaneh, A. K., Ahmad Nurulazam, M. Z., Salmiza, S., \& Abd Ghani, K. (2012). Using Herrmann Whole Brain Teaching Method To Enhance Students' Motivation Towards Science Learning. Journal of Turkish science education, 9(3), 3-22.

[2] Flumerfelt, S. dan Green,G. 2013. Using Lean in The Flipped Classroom for At Risk Student. 16, 356-366.

[3] Herreid, C. F., dan Schiller, N. A. (2013). Case Studies and the Flipped Classroom. Journal of College Science Teaching 42 (5), 62-66.

[4] Jiugen, Y, Ruonan, X, dan Wenting.Z. 2014. Essence of Flipped Classroom Teaching Model and Influence on Traditional Teaching. IEE, 362-365.

[5] Khailani A. Jalil.2011. Falsafah Pendidikan Dan Keperluannya Dalam Proses Transformasi Pendidikan Negara. Jurnal Pendidikan MPSM,Kuala Lumpur (28-36).

[6] Lockwood, K., Bay, C. S.U. M., dan Esselstein,R. 2013. The Inverted Classroom and The CS Curriculum. 113-118.

[7] Mgill, D.S. (2010). What Part of Self Paced Don ${ }^{e e t}$ You Understand?. Proceedings of $24^{\text {th }}$ Annual 
Conference on Distance Teaching and Learning. 05-08 August. Wisconsin, Conal: 1-5.

[8] Mukherjee, T. C. (2013). Exploring the Relationship Between Learner"s Attributes and Flipped Classroom Success in The Malaysian Context. Sarawak: Curtin University Sarawak Malaysia.

[9] Noraini Mohamed Noh, Norazilawati Abdullah, Wong Kung Teck, Mahizer Hamzah. 2017. Keberkesanan Pendekatan Flipped Class Room Dalam Pembelajaran Sains Di Sekolah Rendah. Published : 15 December 2017.

[10]Parsons, J., dan Taylor, L.(2011). Student Engagement: What Do We Know and What Should We Do?.Canada: University Of Alberta.

[11] Stone, B. B. 2012. Flip Your Classroom to Increase Active Learning and Student Engagement, $1-5$.

[12] Toto, R., \& Nguyen, H. N. H. 2009. Flipping the Work Design in an industrial engineering course. 2009 39th IEEE Frontiers in Education Conference. doi:10.1109/FIE.2009.5350529.

[13] Tullis, J.G., dan Benjamin, A.S. 2012. On the Effectiveness of Self-Paced Learning. Journal of Memory and Language. 64(2), 109-118.

[14] Vygostsky, L. (1978). Interaction Between Learning and Development. Mind and Society. United States. Harvard University Press.

[15] Wei Zheng, Timothy Becker, and Xuedong Ding (2014). The Effects of "Flipped Classroom" Concept on the Effectiveness of Teaching. Proceedings, The 2014 ASEE North Midwest Section Conference, October 16-17, 2014. 